\title{
Effect of Deboning Time on the Quality of Broiler Breast Meat (Pectoralis Major)
}

\section{Author(s) \\ Souza PA \\ Kodawara LM \\ Pelicano ERL \\ Souza HBA \\ Oba A \\ Leonel FR \\ Norkus EA \\ Lima TMA}

Departamento de Tecnologia, Faculdade de Ciências Agrárias e Veterinárias - Unesp/FCAV

\section{ABSTRACT}

The present study evaluated the effect of different deboning times on the quality of broiler breast meat. Seventy-two broiler breasts were evaluated. They were distributed in a completely randomized experimental design, with six treatments, six repetitions and two birds per parcel. The treatments were denominated as follows: $A$ - deboning immediately after chilling, B - deboning $1 \mathrm{~h}$ after chilling, $\mathrm{C}$ - deboning 2 $\mathrm{h}$ after chilling, $\mathrm{D}$ - deboning $3 \mathrm{~h}$ after chilling, $\mathrm{E}$ - deboning $4 \mathrm{~h}$ after chilling, and $\mathrm{F}$ - deboning 24 hours after chilling. Lowest $\mathrm{pH}$ values $(p<0.05)$ were seen when deboning was performed $24 \mathrm{~h}$ after carcass chilling $(\mathrm{pH}=6.00)$ in comparison to deboning at $0 \mathrm{~h} \mathrm{(6.69)}$ and $1 \mathrm{~h} \mathrm{(6.42)}$ after chilling. $\mathrm{R}$ values were inversely proportional to $\mathrm{pH}$ values, i.e., $\mathrm{R}$ values were lower $(p<0.05)$ in treatments $A(1.05)$ and $B(1.07)$ when compared to treatment $F$ (1.44). No differences were seen in cooking loss during thermal treatment (broiling) of the muscle $P$. major. Higher shear forces $(p<0.05)$ were seen in broiled muscles from carcasses with shorter storage times (A - $11.78 \mathrm{kgf}$ and $B-10.75 \mathrm{kgf}$ ) before deboning, when compared to treatments $E(6.11 \mathrm{kgf})$ and $F(5.64 \mathrm{kgf})$. Higher $L^{*}$ values were observed in the treatment in which carcass deboning was performed 24 hours after chilling (49.26) in comparison to deboning immediately after chilling (44.68). Therefore, it was concluded that an interval of at least 4 hours is needed between chilling and deboning to obtain broiled breast fillets with tender texture. Furthermore, paler meat color ( $L^{*}$ value) was produced with longer carcass storage before deboning.

\section{INTRODUCTION}

The increasing demand for easily cooking products with high quality and at reasonable prices has caused changes in broiler production systems. The market for chicken parts is nowadays one of the fastest growing segments of the food industry worldwide. According to Seabra et al., (2001), special interest in this area is partially due to the convenience and nutritional value of cuts such as chicken breasts and thighs.

It is known that many factors influence final tenderness in broiler meat, among which pre-slaughter factors (Beraquet, 1999) and postslaughter factors, such as techniques of electrical stimulation and muscle tensioning (Thompson et al., 1987; Cason et al., 1997; Veeramuthu \& Sams, 1999), meat storage conditions (Ventura et al., 2001), thermal treatment (Galvão, 2003) and post-mortem deboning time (Lyon et al., 1998).

According to Lyon et al., (1998) the early harvest of meat from carcasses has raised some concern about texture and juiciness characteristics of filets and other types of breaded chicken portions. 
Souza PA, Kodawara LM, Pelicano

Norkus EA, Lima TMA
ERL, Souza HBA, Oba A, Leonel FR,

Toughness of cooked broiler breast meat continues to be a problem for processors, and postchill deboning time is the most significant factor on the ultimate texture of intact breast meat.

Castillo \& Custódio (2002) described that muscles deboned during early post-mortem period still have energy available for contraction and become rigid if harvested. Thus, 50 to $80 \%$ of the meat that was deboned early ( 0 to 2 hours post-mortem) became rigid. On the other hand, 70 to $80 \%$ of the meat was tender if deboning was performed after an interval of 6 hours, however, this is costly for processors (time, space and energy requirements).

The poultry industry has recently introduced electrical stimulation immediately after death to hasten rigor mortis development of carcasses and reduce aging time before deboning. Such treatment after death results in tender deboned poultry meat within two hours post-mortem instead of the usual aging times of four to six hours. However, electrical stimulation is still being developed and optimized.

In face of such considerations, the objective of the present study was to evaluate the influence of different deboning times on the quality of broiler breast meat.

\section{MATERIAL AND METHODS}

\section{Location}

The experiment was conducted in a commercial abattoir at Pirangi County (SP), a city located at approximately $50 \mathrm{~km}$ from Jaboticabal (SP, Brazil). Analyses were conducted at Laboratório de Tecnologia dos Produtos de Origem Animal from the Departamento de Tecnologia, at Faculdade de Ciências Agrárias e Veterinárias - UNESP, Câmpus de Jaboticabal.

\section{Biological Procedures \\ material and Abattoir}

Slaughter was performed according to the abattoir's ability to provide birds from a single producer, so that homogeneous birds (Cobb strain, 42-day-old males weighing $2.3 \mathrm{~kg}$ of final body weight) and similar conditions of harvesting, transportation and slaughter of birds could be obtained.

Breasts were taken from all of the birds. After a period of feed withdrawal (6 hours) 72 birds were slaughtered following standard procedures: stunning (7 s), bleeding (2 min), scalding for $2.5 \mathrm{~min}$ at $54^{\circ} \mathrm{C}$, defeathering, eviscerating, pre-chilling in water at $20^{\circ}$ $\mathrm{C}$ for $20 \mathrm{~min}$, chilling at $4^{\circ} \mathrm{C}$ for $25 \mathrm{~min}$, and dripping
Effect of Deboning Time on the Quality of Broiler Breast Meat (Pectoralis Major)

for 3 min. After dripping, carcasses were placed into plastic bags and kept on ice until deboning (harvesting of both Pectoralis major). Following deboning, the muscles were packaged, identified and replaced on ice until analysis, i.e., 24 hours after chilling.

\section{Experimental Diets}

Birds were given feed and water ad libitum throughout the experimental period, which was divided in three phases. Initial diets (1-21 days) contained 2,944 $\mathrm{kcal} / \mathrm{kg}$ of metabolizable energy (ME), $23 \%$ of crude protein (CP), $1.285 \%$ lysine (Lys), $0.537 \%$ methionine (Met), $1.001 \%$ Calcium (Ca) and $0.481 \%$ available Phosphorus ( $P$ ). Growing diet levels (22-35 days) were $3,100 \mathrm{kcal} \mathrm{ME} / \mathrm{kg}, 20 \%$ CP, $1.074 \%$ Lys, $0.388 \%$ Met, $0.913 \% \mathrm{C}$ a and $0.377 \%$ available $\mathrm{P}$, and finishing diets (36-42 days) contained 3,200 kcal ME $/ \mathrm{kg}, 18 \% \mathrm{CP}$, $0.935 \%$ Lys, $0.333 \%$ Met, $0.803 \% \mathrm{Ca}$ and $0.327 \%$ available $\mathrm{P}$. Other nutrient levels were according to those recommended by NRC (1994).

\section{Experimental Design and Treatments}

A completely randomized experimental design was used, with 6 treatments, 6 repetitions and two birds per parcel (72 broiler breasts). Treatments were: A deboning immediately after chilling, $B$ - deboning one hour after chilling, $\mathrm{C}$ - deboning 2 hours after chilling, D - deboning 3 hours after chilling, E - deboning 4 hours after chilling and $\mathrm{F}$ - deboning 24 hours after chilling.

Repetitions were processed separately, that is, one at each week (12 birds/treatment/week). Such scheme was followed because it was not possible to debone more than one repetition at the planed intervals. Time intervals were rigorously followed in each treatment; otherwise, the proposed objectives would not be appropriately achieved.

\section{Evaluated Parameters}

The central part of each half breast was used as standard to perform physicochemical analyses. Carcasses and deboned breasts were packaged, identified and replaced on ice until analysis.

\section{- pH}

Raw meat $\mathrm{pH}$ was evaluated (in the same place) at deboning and 24 hours after chilling using a portable pHmeter (model IpHPJ, Jonhis).

\section{- Ratio value ( $R$ value)}

In order to determine the $R$ value, samples were collected at deboning $(0,1,2,3,4$ hours $)$ and 24 hours 
Souza PA, Kodawara LM, Pelicano

ERL, Souza HBA, Oba A, Leonel FR, Norkus EA, Lima TMA after chilling. All samples were immediately frozen in liquid nitrogen. Measurements were made in duplicates, according to the methodology proposed by Honikel \& Fisher (1977). Briefly, nucleotides were extracted from 2-g samples by homogenization for 30 $\mathrm{s}$ (Waring Blender homogenizer) in $1 \mathrm{M}$ perchloric acid $(1: 10 \mathrm{w} / \mathrm{v})$. The homogenate was then filtered and centrifuged for 5 min at 3,000 g (Centrifuge Excelsa II, model $206 \mathrm{MP})$. One aliquot $(0.1 \mathrm{ml})$ of the supernatant was diluted in $4.9 \mathrm{ml}$ of $0.1 \mathrm{M}$ phosphate buffer $\mathrm{pH}$ 7.0. Absorbance was determined at $250 \mathrm{~nm}$ and 260 $\mathrm{nm}$ with a spectrophotometer (Hitachi M V-200), using phosphate buffer as reference. The $R$ value corresponds to the ratio between the concentration of adenine phosphatidyl compounds (ATP, ADP, AMP and others) and the concentration of a major breakdown product, inosine monophosphate (IMP). It was calculated as the ratio between the absorbance at $250 \mathrm{~nm}$ (IMP) and the absorbance at $260 \mathrm{~nm}$ (ATP), and serves as a good monitor of ATP depletion.

\section{- Cooking Losses}

Crude breast muscle samples were weighed and put in trays with aluminum grills previously dried in an incubator. The trays were placed inside the oven until the core temperature of the samples was $80^{\circ} \mathrm{C}$. The samples were then cooled at room temperature; reweighed and cooking loss was calculated as the difference between the initial and the final weight of the sample.

\section{- Shear Force}

The samples used for cooking loss were also used to evaluate shearing force according to the methodology proposed by Froning \& Uijttenboogaart (1988). The samples were placed in the Texture Analyzer TA-XT2i, calibrated with standard weight (5 $\mathrm{kg}$ ) and blade descent speed of $5 \mathrm{~m} / \mathrm{s}$. Fibers were oriented perpendicularly to the Warner-Bratzler blade.

\section{- Color}

Raw meat color was determined using a CR-200 Minolta colorimeter. Three measurements were made at deboning and 24 hours after chilling. Obtained values were expressed in $L^{*}, a^{*}, b^{*}$ (Cielab system), so that $L^{*}$ indicates lightness, $a^{*}$ redness and $b^{*}$ yellowness of the meat.

\section{Statistical Analysis}

Analysis of variance was performed using the software Estat 2.0 (1992) and differences between
Effect of Deboning Time on the Quality of Broiler Breast Meat (Pectoralis Major)

treatment means were evaluated by Tukey's Test at a significance level of $5 \%(p<0.05)$.

\section{RESULTS AND DISCUSSION}

Results of $\mathrm{pH}$ and $\mathrm{R}$ values measured in broiler breast muscle are shown in Table 1. There were no differences among mean $\mathrm{pH}$ values of Pectoralis major muscles harvested immediately after chilling or deboned 1, 2, 3 and 4 hours after chilling. Nevertheless, means from treatment $F$ were significantly $(p<0.05)$ different from treatments $A$ and $B$. Such results partially corroborate the findings reported by Lyon et al. (1985), who observed significantly higher $\mathrm{pH}$ levels in muscles deboned immediately after chilling compared with muscles deboned at 1, 2, 4, 6, 8 or 24 hours after chilling. On the other hand, Sams et al. (1990) reported no significant differences among the final $\mathrm{pH}$ of breast muscles submitted to deboning after defeathering (hot or pre-rigor deboning), after chilling or after 24 hours of carcass storage. The present study has not clearly evidenced until when the $\mathrm{pH}$ decrease is accentuated. Nevertheless, data reported herein agree with the postmortem acidification process that is attributed to the accumulation of lactic acid in the muscle (final product of anaerobic metabolism) (Sams, 1999). However, higher $\mathrm{pH}$ values (6.0) were reported in the present study in comparison to those reported by Pearson (1994) (5.3 to 5.8), suggesting that these birds were probably stressed when they were killed.

\begin{tabular}{|c|c|c|c|c|}
\hline \multirow{2}{*}{$\begin{array}{l}\text { Evaluated } \\
\text { Parameter }\end{array}$} & \multicolumn{2}{|c|}{$\mathrm{pH}$} & \multicolumn{2}{|c|}{ Ratio Value } \\
\hline & At deboning & $24 \mathrm{~h}$ after & At deboning & $24 \mathrm{~h}$ after \\
\hline$A$ & $6.69^{a}$ & 5.90 & $1.05^{b}$ & 1.49 \\
\hline B & $6.42^{a}$ & 6.00 & $1.07^{b}$ & 1.48 \\
\hline C & $6.37 \mathrm{ab}$ & 5.94 & $1.12^{b}$ & 1.49 \\
\hline D & $6.33^{a b}$ & 5.91 & $1.25^{a b}$ & 1.50 \\
\hline$E$ & $6.37 \mathrm{ab}$ & 5.94 & $1.36^{\mathrm{a}}$ & 1.53 \\
\hline $\mathrm{F}$ & $6.00^{b}$ & 6.00 & $1.44^{\mathrm{a}}$ & 1.44 \\
\hline CV (\%) & 3.74 & 3.14 & 9.61 & 9.72 \\
\hline SEM & 0.097 & 0.076 & 0.047 & 0.059 \\
\hline
\end{tabular}

$a, b$ - means followed by different letters within columns are different $(p<0.05)$ by Tukey's test. A - deboning immediately after chilling, B deboning $1 \mathrm{~h}$ after chilling, $\mathrm{C}$ - deboning $2 \mathrm{~h}$ after chilling, $\mathrm{D}$ - deboning $3 \mathrm{~h}$ after chilling, $\mathrm{E}$ - deboning $4 \mathrm{~h}$ after chilling, $\mathrm{F}$ - deboning $24 \mathrm{~h}$ after chilling.

Treatments showed similar pH values 24 hours after chilling. Similarly, Stewart \& Fletcher (1984) also reported that the faster or slower rate at which postmortem muscle $\mathrm{pH}$ changed had no effect on final $\mathrm{pH}$. In other words, the differences in $\mathrm{pH}$ decrease were 
Souza PA, Kodawara LM, Pelicano ERL, Souza HBA, Oba A, Leonel FR, Norkus EA, Lima TMA only temporary in muscle samples submitted to different treatments.

According to Honikel \& Fisher (1977) pre-rigor muscles have high concentrations of nucleotides that contain adenine and the $\mathrm{R}$ value is low; while rigor mortis proceeds, the $R$ value increases. Such information is pertinent, since Table 1 shows that increasing $R$ values were obtained with longer intervals between chilling and deboning. Although such variation was not significant between consecutive intervals, it is evident that a storage period of at least 4 hours is necessary so that the values become stable, i.e., so that $R$ values are not significantly different from muscles that are harvested 24 hours after chilling. As it has already been described, results from treatment $F$ indicate when $R$ values reach a plateau or, in other words, the lowest concentration of ATP that causes minimal muscle contraction.

As show in Table 1, the treatments had no influence on final $R$ value (24 hours after chilling). Similarly, Thompsom et al. (1987) evaluated carcass electrical stimulation for different periods and reported no treatment effects on final $R$ value.

Table 2 shows that there was no influence of treatments on cooking loss of muscle $P$. major after broiling. These findings corroborate results reported by Lyon \& Lyon (1992), who found no differences in liquid loss during the thermal treatment when storage intervals of 0,1 and 24 hours of the whole carcass were used before deboning was performed. According to Dransfield \& Sosnicki (1999), the probability of obtaining meat with lower water holding capacity increases with the development of rigor mortis, and consequently product quality decreases. Nevertheless, this was not observed in the present study.

Table 2 - Cooking loss and shear force values of Pectoralis major breast muscle obtained after thermal treatment of broiled breast muscle.

\begin{tabular}{ccc} 
Evaluated Parameter & Cooking Loss (\%) & Shear Force (kgf) \\
A & 30.80 & $11.78^{\mathrm{a}}$ \\
B & 32.80 & $10.75^{\mathrm{a}}$ \\
C & 29.30 & $9.38^{\mathrm{ab}}$ \\
D & 29.70 & $8.47^{\mathrm{ab}}$ \\
E & 29.30 & $6.11^{\mathrm{b}}$ \\
F & 30.80 & $5.64^{\mathrm{b}}$ \\
CV (\%) & 21.59 & 29.84 \\
SEM & 2.683 & 1.058 \\
\hline
\end{tabular}

$a, b$ - means followed by different letters within the column are different $(p<0.05)$ by Tukey's test. A - deboning immediately after chilling, $\mathrm{B}$ - deboning $1 \mathrm{~h}$ after chilling, $\mathrm{C}$ - deboning $2 \mathrm{~h}$ after chilling, D - deboning $3 \mathrm{~h}$ after chilling, $\mathrm{E}$ - deboning $4 \mathrm{~h}$ after chilling, $\mathrm{F}$ deboning $24 \mathrm{~h}$ after chilling.
Effect of Deboning Time on the Quality of Broiler Breast Meat (Pectoralis Major)

Data of shear force (SF) are presented in Table 2. For broiled muscles, treatments $A$ and $B$ were similar and produced fillets with higher resistance to cut, i.e., tougher meat. Such results corroborate those reported by Lyon et al. (1985), in which muscles deboned just after chilling showed higher shear force when compared to other treatments. Additionally, Craig et al. (1999) reported higher SF $(8.9 \mathrm{kgf} / \mathrm{g})$ in breasts deboned 2 hours after slaughter when compared to breasts submitted to electrical stimulation $(6.5 \mathrm{kgf} / \mathrm{g})$. According to Castillo \& Custódio (2002), rigorfrequently develops in birds from 0.5 to 4 hours after the death. Thus, meat cuts with high SF would be produced if harvested from the carcass during the rigor process. Such observation agrees with the results reported herein, since higher SF was seen in the treatments in which deboning was performed prematurely in the process of rigor.

No differences were seen between treatments $E$ and $F$, which produced muscle with more tenderness (6.11 and $5.64 \mathrm{kgf})$. According to Lyon \& Lyon (1990) and Papinaho \& Fletcher (1996), SF values close to 6.0 kgf are usually considered as moderately tender to tender. Therefore, theoretically, whole carcasses should be submitted to refrigeration for a minimal period of 4 hours before muscle harvesting, in order to produce broiled breast fillets with relatively tender texture. Lyon \& Lyon (1998) reported that broiler breasts deboned and cooked 6 hours after storage showed SF values significantly smaller $(6.21 \mathrm{~kg})$ when compared to $2 \mathrm{~h}$ of storage $(10.39 \mathrm{~kg})$. Northcutt et al. (2001) evaluated slaughter age and the correlation with deboning time and gender on breast meat tenderness. Independent of slaughter age, fillets deboned immediately after slaughter were classified as very tough $(12.6 \mathrm{kgf})$ and fillets deboned 4 or 6 hours after slaughter were classified as moderately tender and tender (6.61 to 3.61).

Treatments influenced $(p<0.05) L^{*}$ and $a^{*}$ values of $P$. major muscle (Table 3 ). Longer intervals before deboning led to a significant increase in meat lightness (44.68 to 49.26). The $L^{*}$ value was not different between treatments $A$ and $D$, but both presented slightly darker muscle when compared to treatment $F$. The low brightness observed in treatments $A$ and $B$ can be correlated to the high final $\mathrm{pH}$ observed and, according Forrest et al. (1979), the higher the $\mathrm{pH}$ values, the darker is the produced meat. Differences in $L^{*}$ values were not seen if measured exactly at 24 hours after chilling.

Treatment $D$ presented meat with higher $(p<0.05)$ value of $a^{*}$ when compared to treatments $A, B$ and $F$. 
Souza PA, Kodawara LM, Pelicano

ERL, Souza HBA, Oba A, Leonel FR,

Norkus EA, Lima TMA

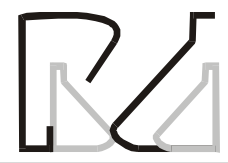

According Castillo \& Custódio (2002) high myoglobin concentration in muscle may indicate pre-slaughter stress and excitation of the birds; however, high values were not seen 24 hours after chilling.

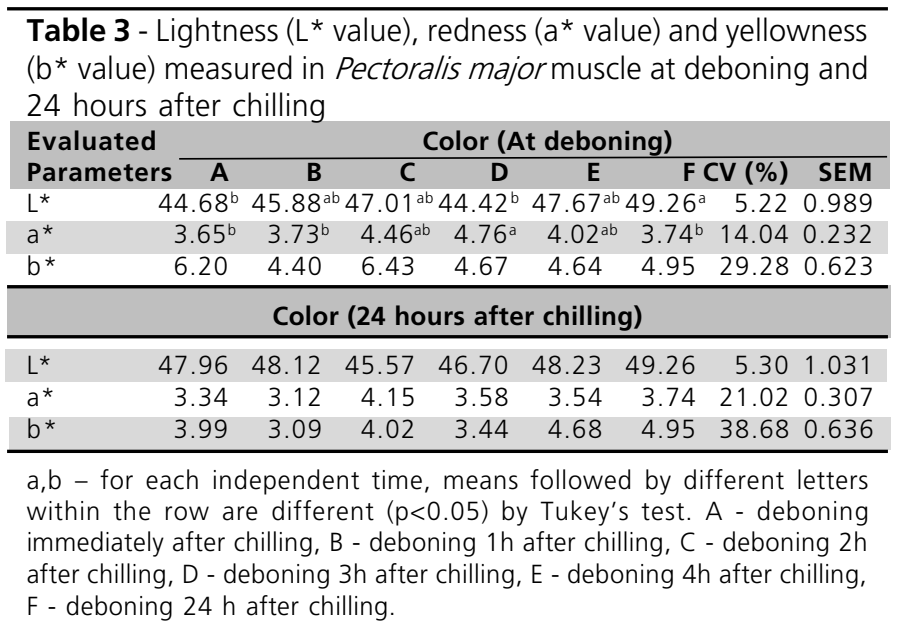

There were no color differences at $24 \mathrm{~h}$, probably because meat lightness and redness changed concomitantly to $\mathrm{pH}$ decrease, i.e., whereas $\mathrm{pH}$ values were unstable. Nevertheless, after the $\mathrm{pH}$ had stabilized (24h), color at the different deboning times showed no significant differences as well. It was also observed that $L^{*}$ values at $24 \mathrm{~h}$ were higher and $\mathrm{a}^{*}$ values at 24 $h$ were lower than $L^{*}$ and $a^{*}$ values at deboning. These findings corroborate results described by Forrest et al. (1979), where meat was darker at higher $\mathrm{pH}$ values, and the opposite was also true.

\section{CONCLUSIONS}

Results indicated that a minimum of 4 hours is required between chilling and deboning in order to obtain broiled breast filets with tender texture. Furthermore, paler meat color ( $L^{*}$ value) was produced with longer carcass storage before deboning.

\section{REFERENCES}

Beraquet NJ. Influência de fatores antee post mortem na qualidade da carne de aves. Revista Brasileira de Ciência Avícola 1999; 1(3): 155-166.

Cason JA, Lyon CE, Papa CM. Effect of muscle opposition during rigor on development of broiler breast meat tenderness. Poultry Science 1997; 76:785-787.

Castillo CJC, Custodio CV. Atributos de qualidade em carcaças de frangos: vale a pena avaliar em nível de produção industrial?. In:
Effect of Deboning Time on the Quality of Broiler Breast Meat (Pectoralis Major)

CONFERÊNCIA APINCO 2002 DE CIÊNCIA E TECNOLOGIA AVÍCOLAS, Campinas, 2002. Anais...p. 31-46.

Craig EW, Fletcher DL, Papinaho PA. The effects of antemortem electrical stunning and postmortem electrical stimulation on biochemical and textural properties of broiler breast meat. Poultry Science 1999; 78:490-494.

Dransfield E, Sosnicki AA. Relationship between muscle growth and poultry meat quality. Poultry Science 1999; 78:743-746.

Estat 2.0 Sistema de Análise Estatística. Jaboticabal: Polo Computacional - Departamento de Ciências Exatas - UNESP; 1992.

Forrest JC, Aberle ED, Hedrick HB, Judge MD, Merkel RA. Fundamentos de Ciencia de la Carne. Traduzido por Bernabé Sanz Pérez. Zaragoza. Acribia 1979, 374p.

Froning GW, Uijttenboogaart TG. Effect of post mortem electrical stimulation on color, texture, $\mathrm{pH}$, and cooking loss of hot and cold deboned chicken breast meat. Poultry Science. Champaign, 1988; 67(11):1536-1544

Galvão MTEL. Análise sensorial de carnes. In: Seminário Avanços na Qualidade da Carne e seus Impactos na Indústria Brasileira. Piracicaba, 2003. Cd Room

Honikel OK, Fisher CA. A rapid method for the detection of PSE and DFD porcine muscles. Journal of Food Science 1977; 42(6):16331637.

Lyon BG, Lyon CE. The relationship of objective shear values and sensory tests to changes in tenderness of broiler breast meat. Poultry Science 1990; 69:1420-1427.

Lyon BG, Lyon CE. Broiler tenderness: effects of postchill deboning time and holding time. Journal of Applied Poultry Research 1992; 1(1): 27-32.

Lyon BG, Lyon CE. Assessment of three devices used in shear tests of cooked breast meat. Poultry Science 1998; 77(10):1585-1590.

Lyon CE, Hamm D, Thomson SE. pH and tenderness of broiler breast meat deboned various times after chilling. Poultry Science 1985; 64(2): $307-310$

Lyon CE, Lyon BG, Dikens JA. Effect of carcass stimulation, deboning time, and marination on color and texture of broiler breast meat. Journal Applied of Poultry Research 1998; 7:53-60.

Northcutt JK, Buhr RJ, Young LL, Lyon CE, Waret GO. Influence of age and postchill carcass aging duration on chicken breast fillet quality. Poultry Science $2001 ; 80: 808-812$

NRC - National Research Council. Nutrient Requirements of Poultry. $9^{\text {th }}$ revised ed. Washington: National Academy of Science Press, 1994. $156 p$

Papinaho PA, Fletcher DL. The effects of stunning amperage and deboning time on early rigor development and breast meat quality of broilers. Poultry Science 1996; 75:672-676. 
Pearson AM. La funcion muscular y los cambios post mortem. Capítulo 4. Ciencia de la Carne y de los Productos Carnicos. PRICE, J.F. \& SCHWEIGERT, B.S. Zaragoza España, $2^{\circ}$ edicion, Editora Acribia, 273p. 1994.

Sams AR, Janky DM, Woodward SA. Comparison of two shearing methods for objective tenderness evaluation and two sampling times for physical-characteristic analyses of early-harvested broiler breast meat. Poultry Science 1990; 69(2):348-353.

Sams AR. Meat quality during processing. Poultry Science 1999; 78(5):798-803.

Seabra LM, Zapata JF, Fuentes MF, Aguiar CM, Freitas ER, Rodrigues MC. Effect of deboning time, muscle tensioning, and calcium chloride marination on texture characteristics of chicken breast meat. Poultry Science 2001, 80:109-112.

Stewart MK, Fletcher DL. The influence of hot boning broiler breast muscle on pH decline and toughening. Poultry Science 1984; 63(10): 1935-1939.

Thompson LD, Janky DM, Woodward SA. Tenderness and physical characteristics of broiler breast fillets harvested at various times from post-mortem electrically stimulated carcasses. Poultry Science 1987; 66(7):1158-1167.

Veeramuthu GI, Sams AR. Postmortem pH, myofibrilar fragmentation, and calpain activity in Pectoralis from electrically stimulated and muscle tensioned broiler carcasses. Poultry Science 1999; 78:272-276.

Ventura H, Galvão MTEL, Ormenese FM. Influência das condições de acondicionamento pós-desossa na textura do filé de peito de frango congelado. In: I Congresso Brasileiro de Ciência e Tecnologia de Carnes, Suplemento, XXXVII-XXXIX, São Pedro/SP, 2001. 